\title{
The research on imputation principle of school sports injury accident
}

\author{
MA Xiao-hua \\ College of PE Taishan University ,Taian ,271021, China \\ e-mail: mxh8682067@163.com
}

Key words: Tort liability law; The school sports injury; The legal responsibility; Duty of care

\begin{abstract}
The promulgation and implementation of "The tort liability act" provide a solid legal basis for the school sports injury accident properly handle. Analyzes the principle of imputation, the components of the liability structure and school responsibility of school sports injury accident through“The tort liability act”. Think the school sports injury accident shall be based on the principle of fault, combined the no-fault principle and fair principle;Tort liability shall meet the requirements of law of four national standard, school sports security attention obligation shall be determined as expert obligation standard.
\end{abstract}

\section{Introduction}

School sports injury accident seriously affected the normal school sports events, and the the adolescent students' physique. How to properly handle is an important topic in front of us. Sports education experts and law experts put forward the solutions from different angles and ways. Take effect on July 1, 2010 of the tort liability law of the People's Republic of China (hereinafter referred to as the tort liability law) for the school sports injury accident properly handle laid a solid legal basis.

\section{The legal definition of school sports injury accident}

The legal definition of school sports injury accident is the premise and foundation,Including the definition of students scope, time, injury accident area definition, type, etc.First, students shall be included in the scope of what level of students.Some scholars pointed out: " The students of school sports injuries mainly refers to the primary and secondary school students, especially the person with limited capacity for civil conduct and do not have competence of civil action." [1]Students area shoulds not be too big, but also cannot too small, should be adapted to common sense of people as well as the needs of social.

Therefore, the study of school sports injury accident not only confined to the primary and secondary schools, should included kindergartens, institutions of higher learning and other education institutions, the different level and age of the students can lead to different imputation principle.Secondly, the time of the school sports injury accident, damage behavior or damage result, there must be one or at the same time in physical education class teaching, extracurricular sports activities, extracurricular sports training and sports competition.

Again, the scope or location of the accident,Requirements damage behavior or damage result must be one or the simultaneous Occur in the physical education teaching, extracurricular sports activities, within the territory after school sports training and sports competition.

So according to the scope of school sports and the "students' injury accident treatment measures ", the school sports injury accident is defined as:The school sports injury is accidents caused the students personal injury or death in physical education class teaching, extracurricular sports activities, extracurricular physical training and sports competition. Students can be kindergarten students also can be a primary and secondary schools and students of institutions of higher learning.

The difference school sports injury accident and the general students' injury accident

Although the school sports injury accident is one of the students' injury accident types, but still has bigger difference with general students' injury accident.

First, the responsibility identification is difficult.School sports injury accident happened in sports activities, sports activities itself is full of intense physical confrontation and competition, hard to avoid the injury accident. 
Sports activities at the same time also have certain rules, foul is allowed within the scope of rules, but also may cause the injury accident;Also, can be the malicious foul use rules, thus caused the difficulty of responsibility identification.

Second, the liabilityof school sports injury accident.School sports activities, the students should undertake all kinds of physical exercises, there is a lot of physical contact, has the characteristics of strong antagonism and fierce competition, prone to accidents.

Old School sports facilities easy cause accident, in P.E. class, the teacher don't have enough time to demonstrate some action on or lack of protection, beyond the syllabus and teachers put forward higher requirements for students, Sports equipment put undeserved, can cause accidents.In the sports meeting, because of the bad organization or athletes inattention (especially when throwing the shot put, discus, javelin), also easy to cause accident.

Third, the parties of school sports injury accident to the accident is generally due to carelessness, negligence, misconduct, is rarely from the intention of intentional injury, sometimes the parties of accidents were no fault.

\section{The legal nature of school sports injury accident}

Yang lixin, Famous civil and commercial law scholar, think:"Student injury accident itself is a kind of tort type, study students' injury accident from the angle of law of tort, to deal with this accident can according to the basic rules of tort law." [2]When professor Yang lixin puts forward the idea, the tort liability act has not enacted, at the time the school sports injury accident and other students' injury accident are on the basis of "general principles of the civil law", "personal injury compensation method" and "method", etc.

But after the tort liability law enacted, according to the provisions of the laws between effectiveness, we should use it as the legal basis of processing. Therefore, the legal nature of school sports injury accident is a kind of infringement.

What is a tort? Yang lixin professor pointed out that "tort refers to the doer due to the fault, don't ask or don't blame in situations because of special provisions in the law, in violation of the provisions of the law of obligation, as or inaction, infringes on the personal rights or property rights and interests, and shall be liable for damages in accordance with the legal consequences of violations".[3]

School sports injury accidents, or due to the fault of the person in charge of the accident or no fault,But a violation of the law of obligations, the form is as or inaction way,

Infringes the personal rights of students, is also likely to invade the property rights of students, we mainly discuss the personal rights of students.

\section{School sports injury accident responsibility imputation principle}

A.The controversy of school sports injury accident imputation principle

The debate of school sports injury accident responsibility principle in adult school students is not big,Here we mainly discusses the school sports injury accident responsibility principle in minor students. Due to the complexity and diversity of personal injury accident of underage student in school,Imputation principle is also varied.

At present,the academia mainly have the following views:

First: Fault liability imputation principle and fair liability principle:

" Through researching the 203 cases of judicial precedent in Beijing for nearly a decade of school sports injury accident,found that such judicial precedent give priority to applying the principle of fault liability, the principle of fair liability as the complement,minors is one of the main victims of the main body, the school is the main responsibility subject." [4]

"the writer think that school sports injury civil liability should be: the principle of fault liability principle is general imputation principle, presumption of fault liability principle is the exception, careful with fair liability principle." [1]Since the school are not the guardian of a minor students, so the legal rights and interests of the students in the school have been violated, can according to the guardian relationship requires schools to assume civil liability for infringement of rights, only when the school has a fault, schools to assume corresponding responsibility.This view is the mainstream view, based on the provisions of article 160 of the "opinions" :"The person who has no capacity for 
civil conduct in kindergarten or school, or mental patients in a mental hospital treatment, injuries or damage to others, the unit has a fault, these units can be ordered to give appropriate compensation."

Second: the fair liability imputation principle

Some scholars believe that the school have responsibility to protect the personal safety of minor students in school, when the minor students accidentally hurt in school, because of no fault party bear the liability for damages, schools even if there is no fault, should also offer certain compensation according to the regulations, otherwise, the students can't get compensation to the damage, violates the fair liability principle of the civil law, in certain cases, the school shall apply fair liability principle. [5]Based on the general principles the 132th regulation of "civil law ":The parties should share the civil liability, according to actual situation, even if there is no fault.

Third: the no-fault liability imputation principle

Some scholars believe that for some special tort, the school shall bear civil liability on the basis of principle of no-fault liability. [6] This point of view is based on "general principles of the civil law" article 106 paragraph 3: "no fault, but the law formulate should bear civil liability, shall bear civil liability".In our current laws and administrative rules and regulations, rarely apply no-fault liability principle.Some special tort of school shall apply the principle of no-fault liability.One of the reason, since the school responsible for the supervision to minor student in school, and guardianship liability is liability without fault.

Second reason, since the law did not make clear on the problem of the imputation principles of regulation of minor students' injury accidents in school, can according to the "general principles of the civil law" the 121th of the provisions of the state organs and their staff posts infringing presumption of school on the school belongs to the harmful accident of underage student special tort, shall bear the liability without fault.

B. The provisions of laws and regulations before the tort liability law enacted

The laws and regulations before the tort liability law enacted mainly the "general principles of the civil law"," the supreme people's court on the implementation opinions on some issues of < general principles of civil law > ", "the supreme people's court on the trial of cases on compensation for personal injury to explain some issues of applicable law "and "students' injury accident treatment method" and so on.Frome the above laws and regulations, the imputation principle of school sports injury accident, can only be applicable to the principle of fault liability as the leading factor, to supplement with fair liability and no-fault liability imputation principle.

C."tort liability law" regulation

The tort liability law article 38: " person do not have civil action competence suffer personal injury during the period of learning or living in kindergartens, schools or other institutions of education, kindergartens and schools or other institutions of education shall bear the responsibility, but can prove to exercise the education and management duties, shall not be responsible."Article 39: "limited capacity for civil conduct in schools or other institutions of education suffer personal injury during learning or living, schools or other institutions of education did not fulfill the education and management responsibilities, shall bear the responsibility."

Therefore, "Tort liability law" specific provision, student injury accident of no capacity for civil conduct suitable for fault-presuming principle, students of limited capacity for civil conduct and full capacity for civil conduct apply the principle of fault liability.

D.The school sports injury accident imputation principle

The author thinks that, according to the stipulations of laws and regulations, the imputation principle of school sports injury accident shall be based on principle of fault presumption ,with fault principle, the principle of no-fault and fair principle to add multiple imputation system. The reason as follows:

First: the presumption of fault principle for general imputation principle conforms to our country legislative spirit and principles. Article 38 of tort liability act defined without civil capacity of students' injury accident apply fault-presuming principle. According to the principle of our country law that special law is superior to the common law, the new law is superior to the old method, when 
the no capacity for civil conduct student happen sports injury accidents, the tort liability act shall apply, rather than the application of the civil law and other laws.

Second: from the perspective of proof ability.

Students without civil action competence are the main part of the school sports injury accident, they are the accident experiencer, but their age and intelligence level of development may not have a better understanding about the accident. In the school sports injury accident, the proof ability of school is superior to students and parents, let students to bear the burden of proof is unfair.School are makers and practitioners of rules and regulations and the teaching activity program, but students are often passive recipients.Accidents ofen happened on campus, is the scope of school management and control. No capacity for civil conduct students, their cognitive ability is very limited, and after the accident, they bear the pain of physical and spiritual shock, let students and parents for preservation and collection of evidence, and prove the school fault are difficult.

Third: the school sports injury accident forensics difficulties. In accordance with the provisions of the civil procedure law, the plaintiff is responsible for the burden of proof in accordance with the principle of fault liability, after the accident, the school often conceals the actual circumstances of the accident in order to their own interests, students and their parents know about the accident, be afraid to tell the truth, the school will have unfair treatment to them, and then choose silence. As a result, students and parents collect the evidence from school to prove school's faultvery is difficult.

Fourth: Although the "tort liability law " has not stipulated the application of the principles of fair liability in the school sports injury accident, but the "general principles of the civil law" the 106th paragraph 3 stipulate the fair responsibility principle. In addition, the cause of the school sports injury accident is varied, but generally use the principle of fault presumption and fault liability principle to pursue the responsibility of the guilty party. But sports activities allow reasonable collision of the body, some sports directly take the human body as a target, such as boxing, karate, judo, wrestling, fencing, etc. Accidents are usually caused by foul exemption within the rules of sports games, as a result, the cognizance of the fault is difficult. Parties of accident are not at fault, cannot use the principle of fault presumption and fault, then the victim of the accident won't get compensation, in this case, can use the fair responsibility principle according to the economic condition of both sides of accident and so on.

Five: the establishment of the principle of no-fault liability. School sports injury accident forms are diverse, and not all injury accident apply fault-presuming principle and fault principle. Damage caused by the mismanagement of school sports equipment shall apply the principle of no-fault liability, Regardless of the school have any fault , as long as the similar accidents, the school should bear corresponding responsibility.

\section{Acknowledgements}

This work was financially supported by the Humanities and social science research project of shandong province colleges and universities (J13WK54),

\section{References}

[1]Han Yong. The theory of tort law under the perspective of school sports injury accident [J]. Journal of sport, 2010 (11) : 39-45.

[2] Yang lixin. tort case and theory [M]. Changchun: jilin people's publishing house, 2003:295.

[3] Yang lixin. Tort liability law [M]. Fudan university press, 2010:3.

[4] Guo Xiujing. From 203 cases of judicial precedent in the school sports injury accident lawsuit imputation problem [J]. Management of primary and secondary schools, 2011 (6) : 27-29.

[5] Xie LiJun. Minor student in the school person damages imputation principle [J]. Journal of teaching and management, 2000, (7) : 25.

[6] Lin Yuanzhi. Theory of several civil legal relationship between school and minor students [J]. Journal of teaching and management, 2000, (7) : 37. 